\title{
Use of Pesticides for Vegetable Crops in Mexico
}

\author{
Ma. A. Pérez-Olvera ${ }^{1}, H$. Navarro-Garza ${ }^{1}$ and E. Miranda-Cruz ${ }^{2}$ \\ ${ }^{1}$ Postgraduates College, \\ ${ }_{2}^{2} J u a r e z$ Autonomous University of Tabasco, \\ México
}

\section{Introduction}

The objective of this research was to analyze and compare the use of pesticides in Mexican horticulture, taking into account: the current Mexican regulation established by the Ministries of Agriculture, Livestock, Rural Development, Fishing and Feeding (SAGARPA), Environment, Natural Resources (SEMARNAT), and Health (SSA); the generalized recommendations according to different institutions linked to agricultural sector; farmers' organizations and companies; in correlation with the production and management practices of the farmers. It must also be considered that an important number of farmers have a limited knowledge of the regulations and lack training in the proper management of conventional and alternative products. Justification is based on the insufficient correspondence between the existing regulations and the emerging problems, registered in later years.

Given its geographic location and its diversity of climates, Mexico has the conditions for growing a great diversity of crops, and thus its agricultural activity is very dynamic. According to data from the INEGI (2007), the agricultural area of the country was 30,2 million hectares, of which 13,9 million were used for annual crops, 8,8 million for perennial crops, and 7,5 million hectares were not cultivated.

Among the agricultural activities, vegetable crop production is one of the most dynamic, due to their short cycle ( 1 to 5 months), which allows obtaining several harvests per year, and a great combination of them, or maintaining the same crop all year long. Some regions of the country have specialized on the production of certain vegetable crops, such as broccoli in Guanajuato, tomato in Sinaloa, chili pepper in Chihuahua, among others. This has allowed destining their products to the domestic as well as the international market. Albert (2005) mentions that in the northeast and central zones (Sinaloa, Sonora, Chihuahua, Baja California, Guanajuato, and Jalisco) important amounts of all kinds of pesticides are used to produce grains and a great variety of vegetable crops for exportation, among them, tomato, Curcubitaceaes (squash, cucumber, etc), and chili pepper.

Cortina (2000) documented the states and zones with the greatest use of pesticides in Mexico: Sinaloa, Chiapas, Veracruz, Jalisco-Nayarit-Colima, Sonora-Baja California, Tamaulipas, Michoacan, Tabasco, State of Mexico, and Puebla-Oaxaca, being the greatest consumer of pesticides Sinaloa with $30 \%$ and the other states with $70 \%$

The products destined to the export market are monitored for safe consumption, being very important the evaluation of the content of pesticide residues, in which case should not exceed the maximum permitted levels (LMRs), as well as of heavy metals and microbiological quality, so that there is no threat to human health. It is also important to monitor these parameters in the water used in the production of these products. 
One of the main problems in intensive crop production, especially in the case of vegetable crops, is the control pest and diseases, which since the green revolution in Mexico, has been historically by means of chemical products. This has caused dependence on the use of agrochemicals, with the implications that it carries to health and ecological impacts. Some researchers point out this generalized problem in certain zones, for example Norzagaray et al. (2010) reports that in Sinaloa (the state with the greatest irrigated surface in Mexico) there is a certain environmental deterioration, which has its main effect on water use. Water is affected by over exploitation of the aquifers, percolation of pesticides and other wastes, causing damages to ecosystems and health. Another important factor of agricultural activities is their economic contribution.

Valdez et al. (2000) mentioned that due to the agrochemical control pest quickly, the farmers use them. The whitefly (Bemisia argentifolli) in the Mexicali Valley, Baja California, is one of the pests that causes great losses in cotton and vegetable crops. Around 800 tons of pesticides are applied in 150,000 hectares in one growing season. Likewise, the use of pesticides restricted and prohibited in Mexico due to their high toxicity has been detected.

There is no precise information on the amount of pesticides currently used in the country, but 6 years ago, it was indicated that around 50000 tons of active ingredient were used annually. The current market value is calculated to be between 400 and 600 million US dollars, although it is possible that this value is lower than it really is (Albert, 2005). In this context, it is important to document the use of pesticides on vegetable crops in Mexico, especially on those of greater importance, considering: regulations, management catalogues as technological reference, specific institutional and research results on pesticide residues, and the proposal of possible alternatives to improve the use of pesticides in vegetable crop production in Mexico.

A revision was done on the main databases of: the Ministry of Agriculture, Livestock, Rural Development Fishing and Feeding (SAGARPA), Service of Agro alimentary and Fishing Information (SIAP), National Institute of Ecology (INE), Inter secretarial Commission for Control and Use of Pesticides, Fertilizers, and Toxic Substances (CICOPLAFEST), National Reference Center of Pesticides and Contaminants (CNRPyC), World Health Organization (WHO), Pesticide Action Network (PAN), and FAO-STAT, among others.

The identification and analysis of technological systems for pest control was based on the gathering of data and creation of a database of the technological packages for each vegetable crop. The prospection universe was very wide, in the sense that the choice was to search for the necessary information, according to the matrix of the main vegetable crops, favoring the technological packages used and/or evaluated by: the National Institute of Agriculture and Livestock and Forestry Research (INIFAP), in its different experimental fields of the horticultural regions; the State Plant Health Administrations; Local farmers' organizations; and in some cases the theses and reports from local universities, among other sources.

A listing was made of the pests and products used to control them, the association between pests and the diversity of products to control them; as well as the listing of products and the spread of their cover among different crops and diverse pests. This information allowed creating a global database of the different vegetable crops. The universe of active ingredients used was classified according to SEMARNAT-WHO (2004). 
Global data bases were analyzed from the National Reference Center of Pesticides and Contaminants (CNRPyC), which depends on the Ministry of Agriculture from 2005 to 2007, corresponding to the results of the national monitoring. There are programs for later years; however, they were not included since there was no access to laboratory results from those years.

From the annual databases, chilli pepper, tomato, squash and some samples of broccoli were select for this study.

The information was analyzed, allowing for the identification and analysis of the main residues from identified active ingredients, and their classification, considering the information provided by the CNRPyC, regarding to permitted, restricted, and prohibited materials, as well as the established LRM. The classification of the pesticides was based on the classification of the Pesticide Action Network (PAN), 2009.

\section{Regulations on pesticides}

Pesticides are regulated in Mexico by the Ministries of environmental, health, plant health, animal health, labor, and regulation for transportation. Also, indirectly, there are diverse customs and foreign trade regulations that must be observed in their handling (Table 1).

The laws involved are: The General Law of Ecological Balance and Environmental Protection, through its regulations on environmental impact regarding dangerous residues; The Federal Law of Plant Health; The Federal Law of Animal Health, Customs Law, General Health Law, through its regulations regarding health control of activities, establishment, products, and services; Federal Labor Law, through its regulations on safety and hygiene at workplaces; and the Law of Roads, Bridges, and Terrestrial Transportation. Specifically, the use of pesticides in Mexico is regulated by CICOPLAFEST (Inter-secretarial Commission for the Control and Use of Pesticides, Fertilizers, and Toxic Substances), constituted in 1987. This Commission includes the Ministries of Agriculture, Environment, Health, and Commerce and Industrial Foment (currently the Secretary of Economy), through a catalogue of registered products and their authorized uses. Its function is to carry out a uniform and integral procedure for the solution of registry requests, authorizations regarding pesticides, fertilizers, and toxic substances, as far as: exploitation, fabrication, formulation, mixing, conditioning, packaging, handling, transportation, distribution, application, storage, commercialization, keeping, use, and final disposal. Moreover, it contains the list of prohibited and restricted products in the country.

In the Official Catalogue of Pesticides, the chemical products are listed, per crop, the pesticides approved for control of plant health problems, safety intervals (days after application before to harvest), and maximum limits of residues authorized for each product (maximum amount of the active ingredient legally allowed in or on the agricultural product obtained, expressed in ppm). It also contains Technical information such as: Chemical name, synonyms, commercial name, formula (\%), presentation, chemical structure, molecular weight, type of pesticide, classification, use, physical and chemical properties, hazard, and persistence. The official catalogue of pesticides constitutes an important reference to achieve a good use and management of pesticides. In conclusion, the only pesticides allowed to be imported, commercialized, and used in Mexico are those that have been registered by the CICOPLAFEST. 


\begin{tabular}{|c|c|}
\hline Health & $\begin{array}{l}\text { NOM-044-SSA-1993, NOM-045-SSA-1993, NOM-046-SSA-1993, } \\
\text { Projects for regulation NOM-058-SSA1-1993 y NOM-043-SSA1- } \\
1993\end{array}$ \\
\hline \multicolumn{2}{|l|}{ Plant Health } \\
\hline $\begin{array}{l}\text { NOM-0320FITO- } \\
1995\end{array}$ & $\begin{array}{l}\text { Health requirements and specifications to carry out studies on } \\
\text { biological effectiveness of agricultural pesticides and their } \\
\text { technical judgment. }\end{array}$ \\
\hline $\begin{array}{l}\text { NOM-033-FITO- } \\
1995\end{array}$ & $\begin{array}{l}\text { Health requirements and specifications to notify start of operations } \\
\text { that physical or moral persons interested in commercializing } \\
\text { agricultural pesticides must fulfill. }\end{array}$ \\
\hline $\begin{array}{l}\text { NOM-034-FITO- } \\
1995\end{array}$ & $\begin{array}{l}\text { Health requirements and specifications to notify start of operations } \\
\text { that physical or moral person interested in making, formulating, } \\
\text { and or working, or importing agricultural pesticides must fulfill. }\end{array}$ \\
\hline $\begin{array}{l}\text { NOM-052-FITO- } \\
1995 .\end{array}$ & $\begin{array}{l}\text { Health requirements and specifications to notify start of operations } \\
\text { those physical or moral persons that are dedicated to aerial } \\
\text { application of agricultural pesticides must fulfill. }\end{array}$ \\
\hline $\begin{array}{l}\text { NOM-057-FITO- } \\
1995\end{array}$ & $\begin{array}{l}\text { Health requirements and specification to emit judgment on } \\
\text { pesticide residue analysis. }\end{array}$ \\
\hline Ecological & NOM-090-ECOL-1994 y NOM-052-ECOL-1993 \\
\hline Animal Health & NOM-023-STPS-1993 \\
\hline Industrial Safety & $\begin{array}{l}\text { NOM-005-STPS-1993, NOM-006-STPS-1993, NOM-009-STPS-1993, } \\
\text { NOM-010-STPS-1993. }\end{array}$ \\
\hline
\end{tabular}

Table 1. Health, Plant Health, Animal Health, and Industrial Safety regulations regarding pesticides

The Federal Law of Plant Health confers to the ministry of Agriculture, Livestock, Rural Development, Fishing and Alimentation the responsibility of regulating and promoting plant health through plant health regulations among which are included the vigilance of biological effectiveness, maximum residue limits, application, use, and management of pesticides.

Table 2 show the lists of prohibited and restricted products in Mexico as well as products prohibited in other countries but allowed in Mexico. It stands out that products such as Endosulfan, Methamidophos, Monocrotophos, among others, less frequent, are commonly used on vegetable crops in Mexico; therefore these products could present restrictions for the export market, depending on the plant health regulations in use. There would be no restrictions for the domestic market, as long as the registry and authorization regulations are respected for a specific crop, and most of all, not going over the PML of the products. 


\begin{tabular}{|l|l|l|}
\hline Prohibited pesticides & $\begin{array}{l}\text { Restricted } \\
\text { Pesticides }\end{array}$ & $\begin{array}{l}\text { Pesticides prohibited in other countries but } \\
\text { authorized in Mexico }\end{array}$ \\
\hline Phenyl acetate & DDT & Alaclor \\
\hline Mercury & BHC & Methamidophos \\
\hline Acid 2,4,5-T & Aldicarb & Azinphos methyl \\
\hline Aldrin & Dicofol & Monocrotophos \\
\hline Cyanophos & Phorate & Captan \\
\hline DBCP & Lindane & Oxyfluorfen \\
\hline Dialifor & Methoxycloro & Methyl-parathion \\
\hline Dieldrin & Mevinphos & Quintozene \\
\hline Dinoseb & Paraquat, & Phosphamidon \\
\hline Endrin & Pentachlorophenol & Tridemorph \\
\hline Erbon & Quintozene & Maneb \\
\hline Formothion & 1,3 & Methidathion \\
\hline Sodium & Dichloropropene & Captofol \\
\hline Fluoroacetate & & Mevinphos \\
\hline Kumisel & & Omethoate \\
\hline Mirex & & Paraquat \\
\hline Monuron & & Diuron \\
\hline Nitrofen & & Phorate \\
\hline Schradan & & Triazophos \\
\hline Triamiphos & & Linuron \\
\hline Thalium sulfate & & 2,4, D \\
\hline Toxaphene & & Endosulfan \\
\hline & & Kulfopros \\
\hline & & Carbaryl \\
\hline
\end{tabular}

Table 2. Prohibited and restricted pesticides in Mexico, and products prohibited in other countries but authorized in Mexico. Source: INE, 2010

\subsection{Agricultural dynamics and vegetable crop production in Mexico}

The cultivated agricultural surface area in Mexico, according to data from the INEGI (2007) is 22,7 million hectares. The most important crops are corn, beans, sorghum, wheat, barley, potatoes, and vegetables.

According to data from the Ministry of Agriculture (SIAP, 2011), the most important vegetables crops, by area cultivated, are 25, which sum up a total surface area of 451036 hectares, and they are: Chili pepper (Capsicum annun), tomato (Lycopersicum sculentum), green tomato (Physalis exocarpa), onion (Allium cepa), squash (Cucurbita pepo), broccoli (Brassica oleraceae var Italica), lettuce (Lactuca sativa), cucumber (Cucumis sativus), carrot (Daucus carota), and asparagus (Asparagus officinalis). From these, the first six were selected (chili pepper, tomato, green tomato, onion, squash, and broccoli), with areas ranging from 140439 and 24396 hectares, for chili pepper and broccoli, respectively. The total national area of the selected vegetable crops is 330487 hectares (Table 3), equivalent to $73,3 \%$. 


\begin{tabular}{|l|l|l|l|}
\hline Product & Principal producing states & $\begin{array}{l}\text { National Total } \\
\text { surface (ha) }\end{array}$ & $\begin{array}{l}\text { Total Surface in } \\
\text { 5 States (ha) }\end{array}$ \\
\hline $\begin{array}{l}\text { Chili } \\
\text { pepper }\end{array}$ & $\begin{array}{l}\text { Chihuahua, San Luis P., Sinaloa, } \\
\text { Durango, Chiapas }\end{array}$ & 140439 & 63319,5 \\
\hline Tomato & $\begin{array}{l}\text { Sinaloa, Michoacan, Baja California, } \\
\text { Veracruz, Zacatecas }\end{array}$ & 52383 & 28779,8 \\
\hline $\begin{array}{l}\text { Green } \\
\text { tomato }\end{array}$ & Sinaloa, Jalisco, Puebla, Mexico, Sonora & 45704 & 26538,3 \\
\hline Onion & $\begin{array}{l}\text { Baja California, Guanajuato, Tamaulipas, } \\
\text { Chihuahua, Puebla }\end{array}$ & 41725 & 24951,2 \\
\hline Squash & $\begin{array}{l}\text { Sonora, Sinaloa, Puebla, Hidalgo, } \\
\text { Michoacan }\end{array}$ & 25840 & 16946,5 \\
\hline Broccoli & $\begin{array}{l}\text { Guanajuato, Michoacan, Jalisco, Puebla y } \\
\text { D.F. }\end{array}$ & 24396 & 22445,5 \\
\hline Total & & 330487 & \\
\hline
\end{tabular}

Table 3. Surface crops of the six principal vegetables in the five most important states producing. Source: Own elaboration with data from the SIAP, 2011.

\section{Technological management for pest control in the main vegetable crops}

The most important vegetable crops in Mexico, according to registries of cultivated surface and production values are: chili pepper, tomato, onion, green tomato, squash and broccoli. Information on other vegetable crops is very disperse, limited, and incomplete.

\subsection{Global analysis}

The products used for pest control have been characterized into two great categories: 1) chemical groups. There is a variety of active ingredients within most of them, through which is commercialized a great diversity of "brands" in the national market, and 2) biological insecticides. Among the 6 main vegetable crops, grown and selected to illustrate the use of pesticides, a total of 97 active ingredients were identified, while only $6(6,2 \%)$ biological insecticides were used.

With regard to registries of insect pests among the main vegetable crops, an important variability was registered, considering the greatest number in the chili pepper crop (19 pests) and the lowest for onion (8). The remaining crops registered: tomato 16 pests, squash 15, green tomato 11, and broccoli 10 . On the other hand, the active ingredients used registered the highest number in squash (71), and the lowest in onion (11). Variability between these two crops registered the following totals: green tomato 33, tomato 24 , chili pepper 23, and broccoli 22 active ingredients. The biological insecticides were used in all the crops, the greatest number of which was registered for squash, with a total of 4 , and only one was registered for onion (Table 4). 


\begin{tabular}{|l|l|l|l|}
\hline Vegetable Crops & Pests & Active Ingredients & $\begin{array}{l}\text { Biological } \\
\text { Insecticides }\end{array}$ \\
\hline Chili Pepper & 19 & 23 & 3 \\
\hline Tomato & 16 & 24 & 2 \\
\hline Onion & 8 & 11 & 1 \\
\hline Green tomato & 11 & 33 & 4 \\
\hline Squash & 15 & 71 & 2 \\
\hline Broccoli & 10 & 22 & 3 \\
\hline
\end{tabular}

Table 4. Main vegetable crops and number of active ingredients and biological insecticides used to control pests. Source: Personal elaboration with data from the SIAP, 2011.

The toxicological classification of the active ingredients in the four typical groupings shows the following results: i/ Slightly toxic with 17 chemical groups and 22 active ingredients, ii/ Moderately toxic with 10 different chemical groups and 34 active ingredients, iii/ Highly toxic with a total of 6 chemical groups and 20 active ingredients, and finally iv/ Extremely toxic made up of 5 chemical groups and 15 active ingredients. Six (6) active ingredients were identified which are not classified (Table 5). The source of classification was CICOPLAFEST (2004), modified from WHO recommended classification of pesticide by hazard and guidelines to classification 2000-2002.

\begin{tabular}{|l|l|l|l|l|l|}
\hline $\begin{array}{l}\text { Toxicological } \\
\text { Class }\end{array}$ & $\begin{array}{l}\text { Extremely } \\
\text { toxic }\end{array}$ & $\begin{array}{l}\text { Highly } \\
\text { toxic }\end{array}$ & $\begin{array}{l}\text { Moderately } \\
\text { toxic }\end{array}$ & $\begin{array}{l}\text { Slightly } \\
\text { toxic }\end{array}$ & Unclassified \\
\hline Chemical groups & 5 & 6 & 1015 & 17 & 0 \\
\hline Active ingredients & 15 & 20 & 34 & 22 & 6 \\
\hline
\end{tabular}

Table 5. Toxicological classification of active ingredients used in the main vegetable crops in Mexico.

According to information from the Pesticide Action Network (2009), the 97 active ingredients used to control pests in the reference vegetable crops were classified. The results show that $60,8 \%$ were classified as highly dangerous. Considering the total of highly dangerous active ingredients, the active ingredients used in all the crops were 3 (Diazinon, Malathion, and Methomyl). A biological insecticide (Bacillus thuringiensis) was registered for the same group of 6 crops. The use of 5 highly dangerous active ingredients (Abamectin, Chlorpyrifos, Endosulfan, Metamide, and Parathion Methyl), one unclassified ingredient (Azinphos-methyl), and no biological insecticides were reported for 5 vegetable crops. The use of 8 highly dangerous ingredients (Carbaryl, Cyromazine, Esfenvalerate, Fenvalerate, Imidacloprid, Lambda-cyhalothrin, Permethrin, and Trichlorfon) was identified in 4 crops. 6 highly dangerous ingredients were registered in 3 crops.

In 2 crops, the registry showed, similarly, 6 highly dangerous ingredients, and two unclassified ingredients. In this group was registered the greatest number of biological insecticides (4). Finally for only one crop, 31 highly dangerous ingredients were registered, 33 unclassified ingredients, and 1 biological insecticide (Table 6). 


\begin{tabular}{|l|l|c|c|c|c|c|c|c|}
\hline \multirow{2}{*}{\multicolumn{2}{|c|}{ Groups }} & \multicolumn{6}{|c|}{ Number crops where the products were } & \multirow{2}{*}{ Total } \\
\cline { 3 - 9 } & 6 & 5 & 4 & 3 & 2 & 1 & \\
\hline $\begin{array}{l}\text { Active } \\
\text { ingredients }\end{array}$ & $\begin{array}{l}\text { Highly dangerous } \\
\text { (HD) }\end{array}$ & 3 & 5 & 8 & 6 & 6 & 31 & 59 \\
\cline { 2 - 9 } & Others, not HD & 0 & 1 & 0 & 2 & 2 & 33 & 38 \\
\hline Biological insecticides & 1 & 0 & 0 & 0 & 4 & 1 & 6 \\
\hline \multicolumn{2}{|l|}{ Total products } & 4 & 6 & 8 & 8 & 12 & 65 & 103 \\
\hline
\end{tabular}

Table 6. Global classification of active ingredient considering highly dangerous classification products of PAN, 2009, and biological insecticides used in the vegetable crops studied.

\subsection{Main vegetable crops in Mexico}

Chili pepper: In the great diversity of regions and production systems destined to growing chili pepper, the existing report shows that 19 pest are controlled with 23 active ingredients and 3 with biological insecticides. The information corresponds to states: Chihuahua, San Luis Potosi, Sinaloa, Jalisco, Tamaulipas, and Baja California Sur.

According to the diversity of insect pests, the number of active ingredients used for their control, and the states where the production systems are registered, the use of 7 active ingredients or products is reported to control the pepper weevil (Anthonomus eugenii Cano), registered in the production systems of 3 states. To control whitefly (Bemisia argentifoliia B\&P and B. tabaci Genn), as well as flea beetles (Epitrix spp.), 6 active ingredients are reported for each, and which are registered in the production systems of 3 and 2 states, respectively.

The diversity of insecticide products, considering the active and biological ingredients, for the control of different pest is presented in Figure 1. The identified products were: Methamidophos is used to control 8 insect pests and its cover extends to 3 states. Endosulfan is used to control 7 pests and is reported in diverse production systems in 6 states. Permethrin is registered for the control of 6 pests and it is used in 3 states. Azinphosmethyl, Carbaryl, Chlorpyrifos, and Spinosad make up a group of active ingredients, each one for the control of 4 pests, in a diverse number of states. The greatest spatial cover (equal to or greater than 3 states) is seen in: Endosulfan: 6 states. Chlorpyrifos: 4 states. Cyromacyne, Methamidophos and Parathion are used in 3 states.

The biological insecticide Bacillus thuringiensis was used for the control of two pests (false inchworm and armyworm -Spodoptera exigua- in Baja California Sur and San Luis Potosí states; Trichogramma sp, registered to control hornworm in San Luis Potosí, and Phaecilomyces fumoroseus.

The toxicological classification of the ingredients and products used on chili pepper registers 4 toxicological classes, within which 9 chemical groups were registered. Also, the use of 3 biological insecticides (Bacillus thuringiensis, Phaecilomyces fumosoroseus, and Trichogramma) was identified. The predominant classes correspond to moderately and extremely toxic, which concentrate, respectively, on $31 \%$ of the total active ingredients. On the other hand, slightly and highly toxic classes were each $19 \%$ of the total. The Extremely toxic chemical groups are: Avermectin, Carbamate, Organophosphorus and insect growth regulator. The Moderately toxic chemical groups are: Carbamate, Macrocyclic lactone (Spinosad), Nicotinoid, Organophosphorus, and Pyrethroid. Three biological insecticides, one organophosphorus ingredient, and one antifeedants were registered in the Slightly toxic class. 


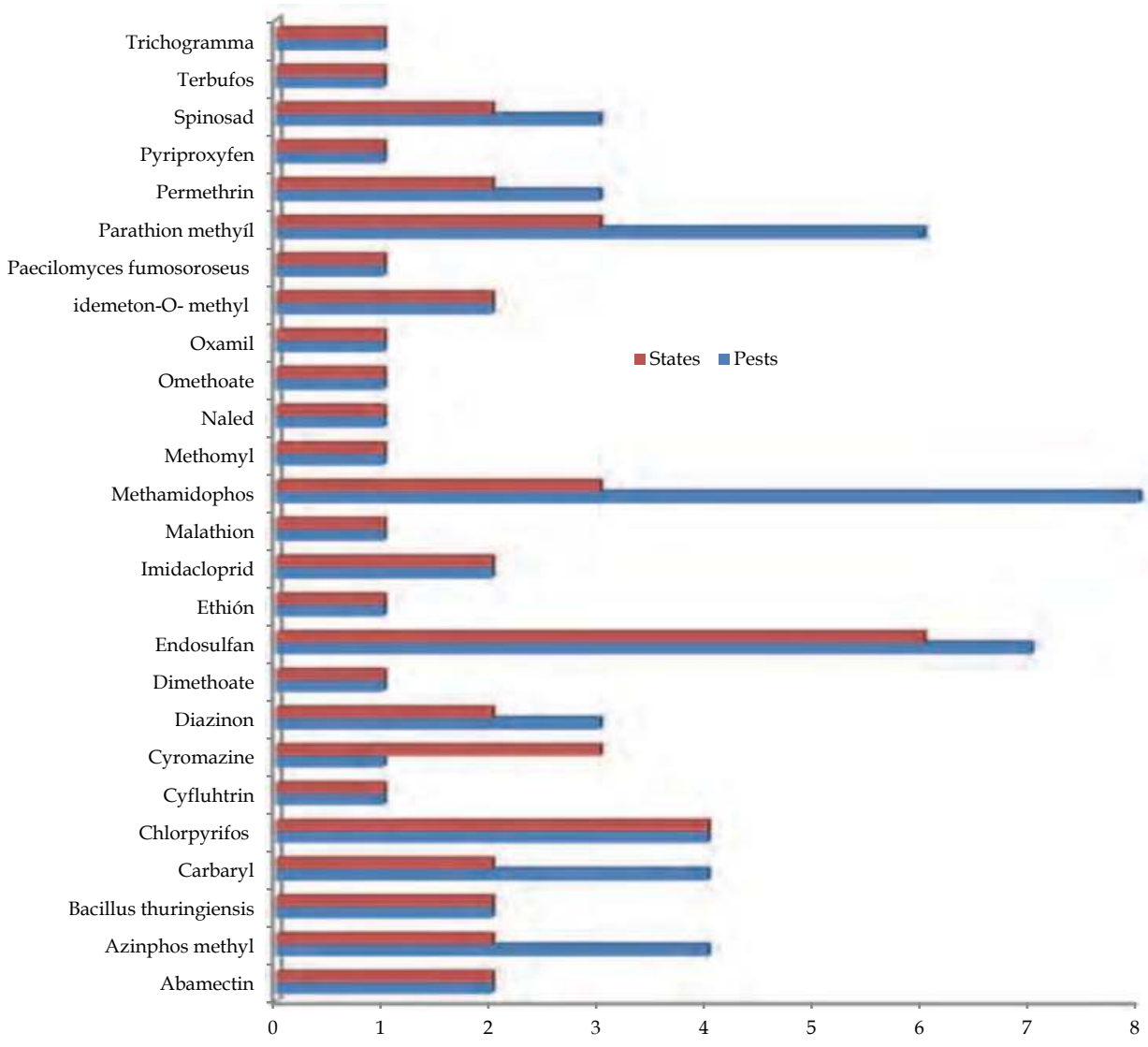

Fig. 1. Active ingredients and biological insecticides, number of pests controlled and total number of states where they are used in the chili pepper crop.

Tomato: There are 16 pests reported in tomato crops, where 24 active ingredients and 2 biological insecticides are used, in 5 main states: Sinaloa, Nayarit, Morelos, San Luis Potosí and Zacatecas. Among the most important insect pests are: the leaf miner (Liriomyza spp.) which is controlled with 12 active ingredients, in production systems of 4 states; secondly is the fruit worm (Heliothis zea and H. virescens), which are controlled with 11 active ingredients-products, in production systems in 5 states. Of similar importance is the whitefly (Bemicia tabaci), which is controlled with 9 active ingredients in production systems of 3 states.

The active ingredient with the most widespread use for pest control is Endosulfan, which is used against 9 pests in the production systems of 4 states. The active ingredients: Abamectin, Indoxacarb, Methamidophos, Permethrin, and Spinosad are used to control 4 different pests each one, with a cover varying from 1 to 3 states. With regard to biological insecticides, the cover is: $B$. thuringiensis is used to control 5 pests in two states, and Paecilomyces fumoroseu is used to control whitefly (Bemicia tabaci) in one state. 
The toxicological classification of the active ingredients and products used on tomato registers all 4 toxicological classes, within which 9 chemical groups were identified.

The Moderately toxic class is the most representative, within which 5 chemical groups were identified (Carbamate, Macrocyclic lactone (Spinosad), Nicotinoid, Organophosphorus and Pyrethroid), among which 12 active ingredients were identified. The next most important class was Highly toxic, where 3 chemical groups were identified (Carbamate, Organochlorates and Organophosphorus), which 6 active ingredients. The Extremely toxic class registered two groups: Abamectin and Organophosphorus, including Methamidophos, Parathion, and Terbufos.

Green tomato. In the production of green tomato are reported 11 pests, for which 33 active ingredients and 4 biological insecticides are used, according to 3 management systems reported in the states of Morelos and Puebla. Among the main pests are: the whitefly (Trialeurodes vaporarioum West) which is controlled with 15 different active ingredients, the leaf miner (Liriomyza trifolii Burgess) and flea beetle (Epitrix cucumeris Harris), which are controlled with 12 active ingredients each, in different state production systems. Less important are: whitefly (Bemicia $s p$ ) and Diabrotica (Diabrotica balteata Le Conte), which are controlled with 9 and 7 active ingredients, respectively in different state production systems. Among the wide diversity of 37 products, there are 34 active ingredients and 3 biological insecticides. Among the most common is: Diazinon, with a wide spectrum of control and is used against 7 pests. On the other hand Monocrotophos, Methamidophos, and Fenvalerate make up a group of active ingredients with a cover of 5 pests controlled. Third in importance are Azinphos methyl, Dimethoate, Endosulfan, and Phosphamidon, which control 3 pests in different states (Figure 2).

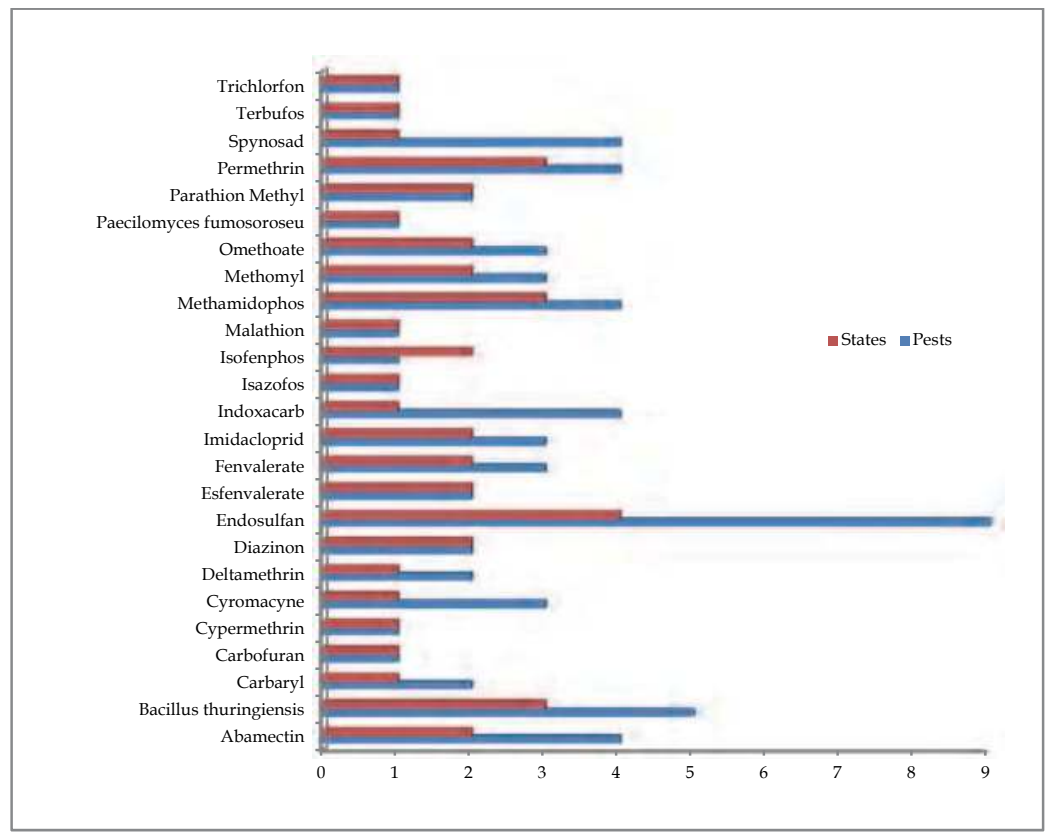

Fig. 2. Toxicological classification and chemical groups in tomato. 
The biological insecticides used were: Bacillus thuringiensis to control fruit worm (Heliothis suflexa Genée); Bauveria bassiana to control whitefly (Bemicia sp), and Trichoderma spp.+ Bacillus subtilis used for plant production.

The toxicological classification of the ingredients and products used on green tomato registers all 4 toxicological classes, within which 14 chemical groups were identified. The most important class was Moderately toxic, with 5 chemical groups (Nicotinoid, Thiazole fungicides -Thiabendazole, Carbamate, Organophosphorus, and Pyrethroid), among which 12 active ingredients were identified. Secondly, the Extremely toxic class was identified with 4 chemical groups (Macrocyclic lactone -Abamectin-, Carbamate, Organophosphorus, and Pyrethroid), among which 10 active ingredients were registered.

Squash. In squash crop, 15 insect pests are reported, for which 71 active ingredients were used, as well as 19 mixtures of them and 2 biological insecticides, in Baja California Sur, Sinaloa and Oaxaca. Among the most important insect pests are: Diverse worm types (Spodoptera exigua, Heliothis armigera, Chrysodesis chalcites, and Autographa gamma), which are controlled with 31 active ingredients and their mixtures, indifferent production systems in 2 states; Greenfly (Aphis gossypii Sulzer), against which 28 active ingredients and mixtures were used, in different production systems in 2 states; Whitefly (Trialeurodes vaporariorum), against which 20 active ingredients and their mixtures are used, in different production systems in one state; Red spider (Tetranychus urticae Koch), against which 16 active ingredients and their mixtures are used, in different production systems in one state; and Trips (Frankliniella occidentalis Pergande), against which 10 active ingredients and their mixtures are used, in different production systems in one state

The active ingredients with the most widespread use for pest control are: Bifenthrin and Deltamethrin, which are used to control 7 insect pests. Second in importance from their cover in controlling 6 pests are: Alpha-cypermethrin, Cypermethrin alone and with sulfur, Fenitrothion, Flucythrinate, Lambda-cyhalothrin, Malathion, and Pirimiphos-methyl. To control 5 pests: Acephate, Chlorpyrifos-methil, Esfenvalerate, Etofenprox, Fenvalerate, Permethrin, Propoxur, and Tralomethrin. The biological insecticides used are: Bacillus thiringiensis $3,2 \%$ to control caterpillars (Spodoptera exigua), (Heliothis armigera), and (Chrysodeisis chalcites) and (Autographa gamma), false inchworm and armyworm and, Bauveria bassiana to control whitefly (Trialeurodes vaporariorum).

The toxicological classification of the ingredients and products used in squash registers all 4 toxicological classes, within which 25 chemical groups were identified. The most important class was moderately toxic, which includes 10 chemical groups, among which 29 active ingredients were identified. Secondly was identified the slightly toxic class with 11 chemical groups, among which 17 active ingredients and 4 unclassified products were registered. On the other hand, there were 5 highly toxic groups (Carbamate, Organochlorine, Organophosphorus, Organotin acaricides, and Pyrethroid), among which were 16 active ingredients. Finally, 4 chemical groups were registered from the extremely toxic class (Macrocyclic lactone -Avermectin-, Carbamate, organophosphorus and Pyrethroid), with 9 active ingredients.

Onion. In onion crop, 8 insect pests are reported, for which 11 active ingredients and one biological insecticide are used, in 6 states: Baja California Sur, Chihuahua, Guanajuato, Morelos, Tamaulipas, and Zacatecas. Among the most important insect pests are: Trips (Thrips tabaci Lindeman), which is controlled with 11 active ingredients in different production systems in 5 states; Leaf miner, against which 7 active ingredients are used in different production systems in 4 states; and armyworm (Spodoptera exigua Hubner), against which 4 active ingredients are used in different production systems in 4 states. 
According to the widespread use of the active ingredients to control pests, there are: Azinphos-methyl and Diazinon, which control 5 insect pests, used in production systems of 5 states; second in importance are Malathion, which controls 4 pests in production systems of 5 states, and Methomil, which controls 3 insect pests in production systems in 4 states. The biological insecticide used was Bacillus thuringiensis to control armyworm (Spodoptera exigua Hubner) in two states.

The toxicological classification of the ingredients and products used in onion registers all 4 toxicological classes, within which 4 chemical groups were identified, as well as Bacillus thuringiensis as biological insecticide. The most important class was extremely toxic, which is made up of 2 chemical groups (Macrocyclic lactone and Organophosphorus), among which 4 active ingredients were identified. Secondly was the Moderately toxic class with two chemical groups (Pyrethroid and Organophosphorus), among which 3 active ingredients were registered. Then, there were 2 Higly toxic groups (Carbamate and Organophosphorus), with 2 active ingredients. Finally, there were 2 Slightly toxic groups with 2 chemical groups (Organophosphorus and Antifeedants -Pymetrozine), among which were 2 active ingredients

Broccoli. In broccoli, 10 insect pests are reported, for which 22 active ingredients are used, 1 mixture, and 3 biological insecticides, in different production systems in 4 states: Aguascalientes, Guanajuato, Morelos, and Sinaloa. Among the most important insect pests are: Imported cabbage worm, which is controlled with 11 active ingredients and 1 biological insecticide in different production systems in 3 states; Diamondback moth (Plutella xylostella), against which 9 active ingredients and 2 biological insecticides are used in different types of production systems in 2 states; Cabbage heart worm, which is controlled with 9 active ingredients and 1 biological insecticide in different types of production systems in 2 states. A group of 3 insect pests: Harlequin cabbage bug (Murgantia histrionic Hahn), False inchworm (Trichoplusia ni), and Armyworm (Spodoptera exigua), each controlled with 9 different products (active ingredients and biological insecticides), respectively, in production systems of 1,2 , and 1 states.

According to the importance of the cover of the active ingredients to control pests, there are: Methamidophos, used to control 7 insect pests in production systems in one state; secondly important are Azadirachtin, Fenvalerate, Parathion-methyl and Permethrin, registered to control 5 pests each, used in production systems in 1 state; finally in importance to control pests are: Azinphos-methyl, Endosulfan, Naled, and Trichlorfon, used in 1 and 2 states The biological insecticides used were: Bacillus thuringiensis to combat 6 pests, Diadegma and Trichogramma to combat 4 pests.

The toxicological classification of the ingredients and products used in broccoli registers all 4 toxicological classes, within which 7 chemical groups were identified, and 3 biological insecticides. The most important class was that of Moderately toxic, made up of 4 chemical groups, among which 11 active ingredients were identified. Second in importance was Extremely toxic, which has only one chemical group (Organophosphorus), with 5 different ingredients (Azinphos-methyl, Methamidophos, Monocrotophos, Naled, and Parathionmethyl). There were 3 Highly toxic groups (Macrocyclic lactone, Carbamate, and Organochlorine), among which were 3 active ingredients. Lastly, there were Slightly toxic with 2 chemical groups (Distillates (Petroleum paraffinic petroleum oil- and Organophosphorus), among which are 3 active ingredients (Table 7) 


\begin{tabular}{|c|c|c|c|}
\hline Extremely & Highly & Moderately & Slightly \\
\hline \multirow{2}{\text{Organophosphorus}}{$\begin{array}{c}\text { Avermectin (1) } \\
\text { Carbamate (1) }\end{array}$} & $\begin{array}{c}\text { Carbamato (1) } \\
\text { Espinosina(1) } \\
\text { Organochlorine } \\
(1)\end{array}$ & $\begin{array}{c}\text { Organophosphorus (4) } \\
\text { Pyrethroid (5) }\end{array}$ & $\begin{array}{c}\text { Alifatic (2) } \\
\text { Organophosphorus } \\
(1)\end{array}$ \\
\hline
\end{tabular}

Table 7. Toxicological classification and chemical groups: broccoli

\section{Pesticide residues in crops}

In Mexico, there are no official antecedents on the monitoring of unauthorized pesticides in agricultural products. At institutional level, there were only studies, and the information generated came from countries importing agricultural products, which rejected shipments containing residues from pesticides without a LMR, or when these were greater than the allowed levels (CNRPyC, 2011). The National Center for Reference of Pesticides and Contaminants (CNRPyC) was established in 1991 as a normative reference center, for the development of training methods regarding pesticide residue analysis. It is part of the General Direction of Water and Fishing Agroalimentary Health (DGIAAP), which was created in 2003 with the responsibility of working on health safety of foodstuffs from land and sea, through health standards required by the domestic and international market.

The CNRPyC carries out an annual follow-through and evaluation program at national level in zones where there have been malpractices regarding the use and application of pesticides. This program has focused on establishing strategies that will allow designing operational plans, though which can be achieved awareness of the producers through training and assistance programs by the personnel from the State Delegations of the SAGARPA, where the good use and management of pesticides will be promoted. This will reflect on the production of harmless products, free of pesticide residues, which in turn will be reflected on the health of the consumers and farmers producers.

The role of the CNRPyC is to help in the coordination and application of the program with the State Delegations. The regions and crops to be considered in the monitoring were taken into account based on the presence of unauthorized pesticide residues detected and reported in the analyzed samples. Currently, there are results of pesticide residues from the samples analyzed from 2005-2007, and programming data from the 2008 monitoring.

\subsection{National monitoring 2005-2007}

The pesticides products not authorized for some crops were detected by the CNRPyC, (2011), found 19, 15 y 17 for 2005, 2006 and 2007 respectively (Table 8). The products not authorized are: Permethrin, Omethoate, Monocrotophos, Chlorothalonil, Parathion methyl, Methamidophos, Acephate, Endosulfan, Dimethoate, Pentacloroaniline, Cypermethrin, Chlorpyrifos, Isozofos, Quintozene, Dichlorvos, Acetochlor, Dicrotophos, Pentachlorobencene, Diazinon, Folpet, Iprodione, Ethion, Lamda cyalotrine, Profenophos.

From the analyzed samples, approximately $12 \%$ of the products are destined to the domestic market. The main commercialization sites are supply depots in: Puebla, Cuautla, Mexico City, Hermosillo, Chihuahua, Monterrey, Torreon, Guadalajara, Tamaulipas, and other local and regional markets. The destinations of the products of the exportation market to the United States (California and Arizona, among others) are equivalent to approximately $87 \%$. 


\begin{tabular}{|l|l|l|l|l|}
\hline & 2005 & 2006 & 2007 & $2008^{*}$ \\
\hline Total samples & 335 & 337 & 323 & 308 \\
\hline $\begin{array}{l}\text { States participating in the } \\
\text { sampling }\end{array}$ & $\begin{array}{l}16 \text { and } \\
\text { one } \\
\text { region }\end{array}$ & $\begin{array}{l}16 \text { and one } \\
\text { commercial } \\
\text { center }\end{array}$ & $\begin{array}{l}12 \text { and } \\
\text { one } \\
\text { region }\end{array}$ & $\begin{array}{l}19 \text { and } \\
\text { one } \\
\text { region }\end{array}$ \\
\hline Monitored crops & 44 & 49 & 41 & 17 \\
\hline Samples for Exportation market & 42 & 38 & 42 & - \\
\hline Samples for domestic market & 290 & 299 & 281 & - \\
\hline Non authorized products & 19 & 15 & 17 & \\
\hline Restricted & 7 & 6 & 6 & \\
\hline Canceled samples & 7 & & & \\
\hline
\end{tabular}

Table 8. Participating states, crops and characteristics of the samples analyzed in the national Monitoring for the quantification of pesticide residues 2005-2007. Source: own elaboration with data available from the CNRPyC; ${ }^{*}=$ programmed

The results of the analysis of the 335 samples in 2005, in which 424 determinations were made, showed that 93 samples were free of pesticide residues, however 248 samples were found with the presence of at least one residue, 33 samples with two and 25 with 3 residues. Only a small proportion submitted more 3 pesticides residues. The most frequently product residues found were: Methamidophos, Endosulfan, Chlorpyrifos, Omethoate, Dimethoate and Acephate, Permethrin, Monocrotophos (Figure 3).

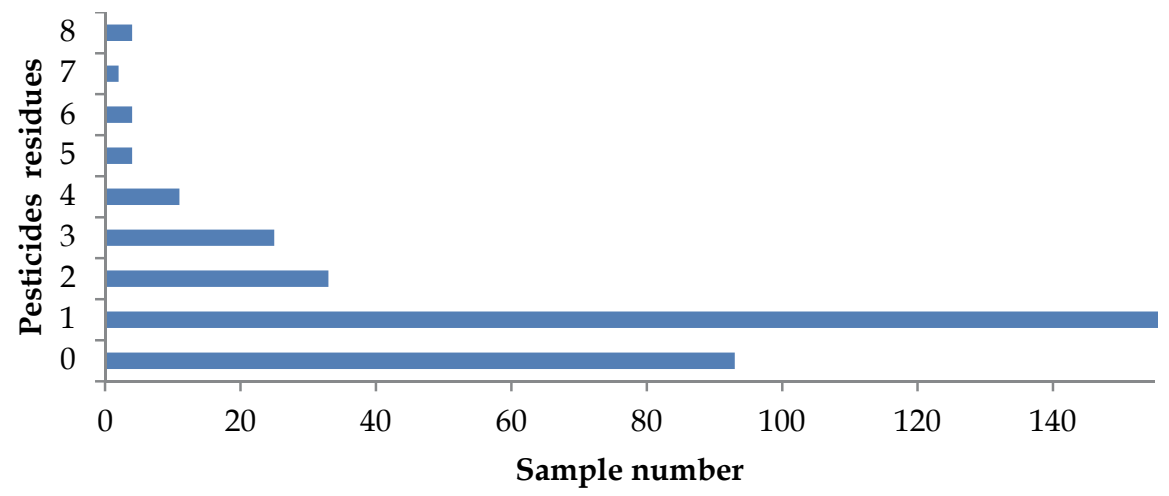

Fig. 3. Pesticides residues found in vegetable samples, 2005.

An important part to achieve a correct use and management of these products is to maintain the users and plant health professionals informed on the authorized pesticides, whose biological effectiveness has been positively evaluated in the field, as well as what the doses, time and number of applications, and safety intervals (days elapsed between the last application and harvest) that have to be observed in the use of pesticides. Likewise, the technicians from the SAGARPA must be updated in the knowledge of the products whose effectiveness in pest control has been proven, so they can carry out an adequate vigilance on their use and application. 
According to the results found (Figure 4), almost $30 \%$ of the analyzed samples were free of pesticide residues. The pesticides more frequently found were Methamidophos, Endosulfan, Chlorpyrifos, Omethoate y Dimethoate. The different active ingredient found in the samples from 2005 to 2007 were 31.

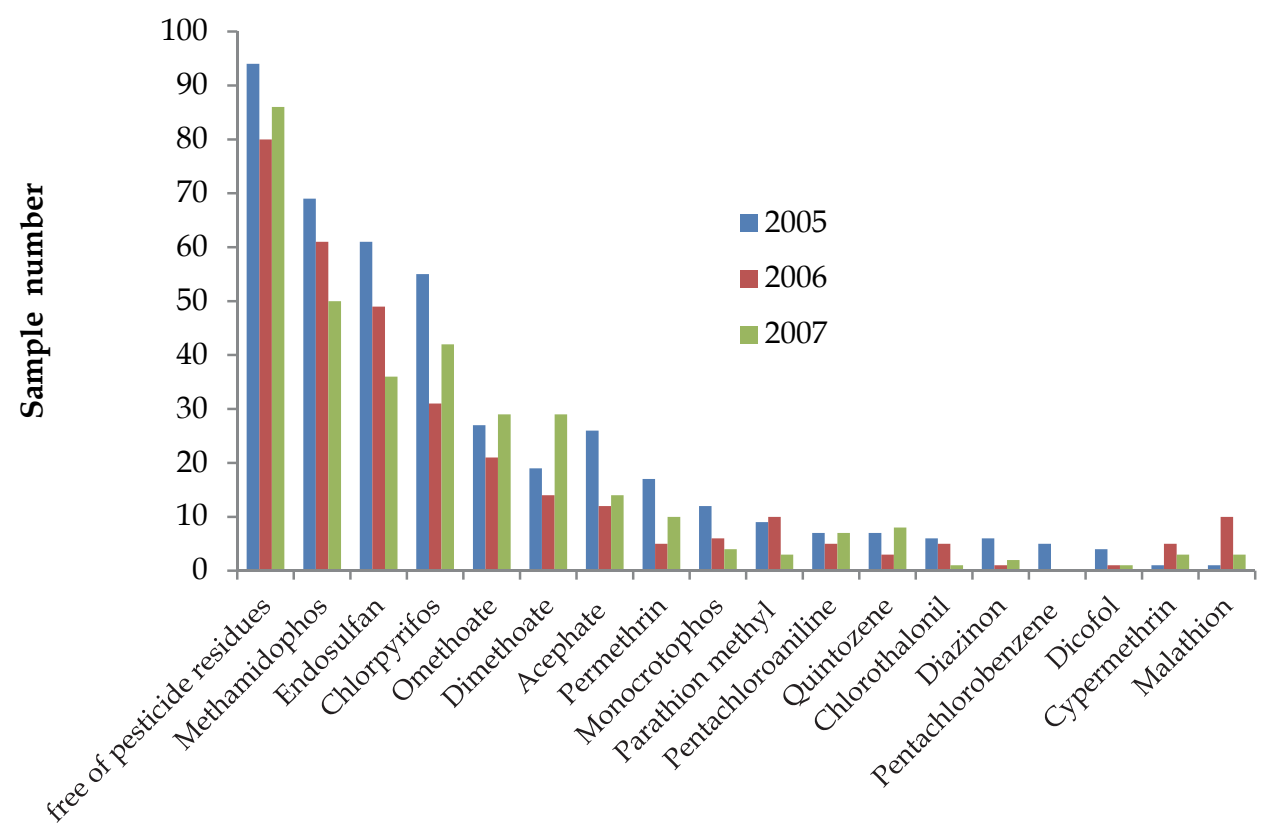

Fig. 4. Pesticides residues in diferents crops 2005-2007.

\subsection{National sampling for the main vegetable crops}

The National Reference Center of Pesticides and Contaminants (CNRPyC), has carried out during 2005, 2006, and 2007 several samplings of pesticide residues in different agricultural systems and states in Mexico. Among the crops of economic interest for Mexican agriculture were selected: chili pepper, tomato, squash, and broccoli.

\subsubsection{Global multiannual analysis}

During 2005-2007, 406 samples of vegetable crops of interest were analyzed, in which a total of 665 determinations were identified in the three years.

The analysis indicates that in 156 determinations of the 4 crops analyzed $(23,5 \%)$ no residues were detected; in 391 (58,8\%) residues from authorized active ingredients were detected; in $113(17 \%)$ residues from unauthorized active ingredients were detected; in 5 of the determinations the active ingredients are over the LMR, established for the products; in 2 determinations residues were identified as restricted active ingredients, and in one of them a prohibited active ingredient was identified (Table 9). 


\begin{tabular}{|l|l|}
\hline & $\begin{array}{l}\text { Samples number or } \\
\text { determinations }\end{array}$ \\
\hline Total samples & 406 \\
\hline Total determinations & 665 \\
\hline Active ingredients undetected & 156 \\
\hline Authorized active ingredients & 391 \\
\hline Unauthorized active ingredients & 113 \\
\hline Active ingredients exceeding LMR & 5 \\
\hline Restricted active ingredients & 2 \\
\hline Prohibited active ingredients & 1 \\
\hline Determination without data & 5 \\
\hline
\end{tabular}

Table 9. Global analysis of residues samples in chili pepper, tomato, squash, and broccoli, during 2005 to 2007

\subsubsection{Authorized active ingredients in the main vegetables}

15 authorized active ingredients were identified: Bifenthrin, Clomazone, Chlorpyrifos, Chlortal-dimethyl (Dactal), Cyanofos, Diazinon, Dimethoate, Endosulfan, Ethion, Lambacyhalothrin, Malathion, Methamidophos, Mevinphos, and Quintozene. The total of authorized active ingredients per year was: 172, 114, and 105 in 2005, 2006, and 2007, respectively. The authorized active ingredients that were detected most frequently were: Methamidophos (extremely toxic organophosphorus) with 114 registries, representing 34\%; Endosulfan (highly toxic organochlorine) with 99 registries $(29,6 \%)$, and Chlorpyrifos (highly toxic organophosphorus) with 74 registries, equivalent to $22,1 \%$ of the total. In general, it can be seen that these three active ingredients make up $85,7 \%$ of the determinations of authorized ingredients.

\subsubsection{Unauthorized active ingredients}

A total of 15 unauthorized active ingredients were identified: Acefate, Acetoclor, Cipermetrina, Cloratonil, Clorpirifos, Dimetoato, Folpet, Iprodione, Isazofos, Monocrotofos, Omethoate, Paration metílico, Pentacloroanilina, Permetrina, and Profenofos. The total of unauthorized ingredients found was 118: 52 determinations with different residues in 2005, 33 in 2006, and 28 in 2007.

The unauthorized active ingredients detected most frequently were: Omethoate (highly toxic organophosphorus) with 40 registries (35,4\%); Monocrotophos (highly toxic organophosphorus) with 20 registries (17,7\%); Acephate (slightly toxic organophosphorus) with 19 registries $(16,8 \%)$; and Permethrin (slightly toxic pyrethroid) with 14 registries $(12,4 \%)$. These four made up $82,3 \%$ of the total unauthorized ingredients

In squash, residues from 5 active ingredients were found, among which the most frequent were: Endosulfan with a total 7 samples in the states of Baja California, Puebla, and an unidentified site; Metamidophos with a total 5 samples in the states of Baja California, Oaxaca, and Puebla; and the group made up of Acephate, Dimethoate in different states.

In tomato, residues from 9 active ingredients were identified. The most frequent of these were: Endosulfan in 12 determinations in the states of Baja California, Oaxaca, Sonora, and the Laguna region, besides 3 unidentified sites; Metamidophos with 11 determinations in 
the states of Chihuahua, Oaxaca, Sinaloa, and Sonora, besides 5 unidentified sites; Chlorpyrifos with 6 determinations in the states of Michoacan, Sinaloa, and the Laguna region. A group made up of Acephate and Omethoate, with 4 determinations each. The first of these was unidentified in 4 sites and the latter in the states of Michoacan and Sinaloa and Omethoate, each of which was reported in two different samples.

In chili pepper crops, residues from 11 active ingredients were registered, among which the most frequent were: Chlorpyrifos (slightly toxic organophosphorus) with a total 17 determinations in the stated of Aguascalientes, Guanajuato, Michoacan, Sinaloa, and the Laguna region besides 5 unidentified sites; Methamidophos (extremely toxic organophosphorus) with a total 16 positive results in the states of Baja California, Chihuahua, Michoacan, San Luis Potosi, and the Laguna region; and a group made up of Endosulfan (highly toxic Organochlorine) and Omethoate (highly toxic Organochlorine), each one reported on 9 determinations; the first of these in the states of Baja California and San Luis Potosi, and the latter in three states: Guanajuato, Michoacan, and Zacatecas.

\section{Final reflection}

Bolognesi (2003) and Mansour (2004) mention that pesticides are the most common products used to control agricultural pests, specifying that a correct application is the most accepted and effective measure to achieve maximum production and best quality in the crops. However, in Mexico, the tendency to the specialization of certain crops in specific zones and/or states generates a predominance of monocrops growing and an increase in the frequency of incidence of typical pests. Consequently, there is a greater number of applications of agrochemicals to control the pests, an increase in the recommended doses, use of products successful in controlling a certain pest on crops on which they are not authorized, and there are even reports where the trust interval for the products is not respected. Such evidences converge to explain, as the main causes, the presence of pesticide residues in agricultural products, especially in vegetable crops. However, in most cases, the pesticides residue in the samples analyzed do not exceed the permitted maximum limits. Moreover, the CICOPLAFEST (1998) and Bolognesi (2003) mention that there is a great diversity of products in the market, given that the industry of agrochemicals in the XX century has developed a great number of new compounds that are highly aggressive to human health, and which have caused noxious effects that have broken the balance of the ecosystem.

The Pesticide Action Network (PAN, International, 2009), on classifying pesticides according to their level of danger, even proposing the elimination of some of the more dangerous ones, has been the organization that has identified and integrated the factors that are dangerous to the ecosystem, and to human health in the long term, among others.

It is necessary the use of agricultural practices to reduce the use of pesticides. Some options are: incorporation of biological control measurement, the use of integrated pest management, respecting authorized products, doses, and trust intervals per crop, being among the most important (Martinez and Gomez, 2007; Perez et al., 2009).

Is also of important to intensify efforts in training and permanent updating of the technical personnel, laborers, and farmers, as well as fortifying actions to prevent and educate the community (Martinez and Gomez, 2007). Moreover, the production processes of the producers or zones where products have been obtained free of pesticide residues must be valued and taken into account, in order to integrate proposals of technological packages that can be upgraded to regional levels. 
Monitoring of agricultural products must be permanent, especially in the horticulture sector, which has the most intensive use of pesticides (Perez et al., 2009) and monitoring of laborers and pesticide users must be considered as an integral part of a good medical vigilance in people, since it allows to take the necessary actions on early identification of genetic risk (Martinez and Gomez, 2007).

\section{Conclusions}

In Mexico, the use of pesticides in horticulture is regulated by the Mexican norms and regulations in use, as established by the Secretaries of: Agriculture and Livestock, Environment, and Natural Resources, which make up the Intersecretarial Commission for Control and Use of Pesticides, Fertilizers, and Toxic Substances. Its coordination and regulations are concreted in a national catalogue, which functions as the global reference framework to orient and achieve the good use and management of pesticides, considering that it integrates a list of pesticides whose importation, commercialization, and use are allowed in Mexico.

In the case of horticultural products, particularly for the exportation market, the importing countries have proven to be very rigorous in their regulations regarding residues from pesticides and other contaminants. Because of this, samplings are done to guarantee the quality of the vegetable crops that go into their countries, considering a zero tolerance in the cases of organic or ecological agriculture, and that the maximum allowed limits established for authorized pesticides for conventional crops are not exceeded. Consequently, the farmers who establish their crops for the exportation market have to use only those products that are authorized in the country where their products are intended to export. In some cases, there is even a contractual agriculture, where the farmer commits himself to applying a technological package that includes the products and technical assistance.

In the six vegetable crops analyzed, there are between 8 and 19 pests. The outlier values correspond to onion and chilli pepper, respectively. For the group of these vegetable crops, 97 active ingredients and 6 biological insecticides were identified. The use of active ingredients was greatest in squash $(73,2 \%)$, and the lowest was in onion $(11,3 \%)$. Biological insecticides represent $5,8 \%$ of the products used to control pests, with 1 to $4,1 \%$ in onions and green tomato, respectively.

The toxicological classification of the active ingredients in the corresponding categories is as follows: i/ Slightly toxic with 17 chemical groups and 22 active ingredients, ii/Moderately toxic with 10 chemical groups and 34 active ingredients, ii/Highly toxic with 6 chemical groups and 20 active ingredients, and iv/ Extremely toxic with 5 chemical groups and 15 active ingredients. There were also 6 unclassified active ingredients identified.

According to the classification by the PAN, 2009, the pesticides reported in the group of vegetable crops makes up $60,8 \%$ of the total identified active ingredients. Among them, Diazinon, Malathion, and Metomilo were used in all vegetable crops; Abamectina, Chlorpyrifos, Endosulfan, Metamidophos, and Parathion-methyl were used in 5 crops; and Carbarilo, Cyromazina, Esfenvaleranto, Fenvalerato, Imidacloprid, Lambda-cihalotrina, Permetrina, and Triclorfon were all used in three crops.

The results from the national sampling of production systems during 2005, 200, and 2007, in different vegetable producing states, showed for a cover of chili pepper, tomato, squash, and broccoli 4 of the vegetable crops identified as the most important ones- the following data: 406 samples, among which several residue analyses were done, giving off results from 665 
analytical laboratory determinations. The total determination analysis proved that: i) in $23,5 \%$ of the samples no residues were found, ii) in $58,8 \%$ of the samples residues from authorized active ingredients were found, iii) in $17 \%$ of the samples residues from unauthorized active ingredients were found, for any of the 4 crops in study, iv) in 5 of the determinations, the active ingredients detected were over the established limit, and v) one of the determinations showed a prohibited active ingredient.

The authorized active ingredients that were detected registered a total 15 different molecules: Bifentrina, Clomazone, Clorpirifos, Clortal-dimetil (Dactal), Cyanofos, Diazinon, Dimetoato, Endosulfan, Etion, Lamba-cialotrina, Malation, Methamidophos, Mevinfos, and Quintozeno. The authorized active ingredients that were detected with the greates spatialtemporal frequency were: Methamidophos, with 114 registries, representing $34 \%$ of the total; Endosulfan, with 99 registries $(29,6 \%)$, and Clorpirifos, with a total 74 registries, equivalent to $22,1 \%$ of the total. The toxicological classification of these three active ingredients is: Metamidophos as an extremely toxic osganofosforado, Endosulfan as a highly toxic Organochlorine, and Clorpirifos as a slightly toxic organophosphorus. On the whole, it can be seen that these three active ingredients (Methamidophos, Endosulfan, and Clorpirifos) were detected in $85,7 \%$ of the determinations of authorized ingredients.

Grouping of the unauthorized active ingredients allowed to identify residues from a total of 15 different molecules, among them: Acefate, Acetoclor, Cipermetrina, Cloratonil, Clorpirifos, Dimetoato, Folpet, Iprodione, Isazofos, Monocrotofos, Omethoate, Paration metílico, Pentacloroanilina, Permetrina, and Profenofos.

The unauthorized active ingredients detected with the greatest spatial-temporal frequency were: Omethoate with 40 registries (35,4\% of the total), Monocrotofos with 20 registries $(17,79 \%)$, Acefate with 19 registries (16,8\%), and Permetrina with 14 registries $(12,4 \%)$. The toxicological classification of these 4 active ingredients is: Omethoate as a highly toxic organophosphorus, Monocrotofos as an extremely toxic organophosphorus, and Acefate and Permetrina both as slightly toxic, organophosphorus and piretroide, respectively. On the whole, it can be seen that these four active ingredients (Omethoate, Monocrotofos, Acefate, and Permetrina) were detected in $82,3 \%$ of the total determinations of unauthorized ingredients.

\section{References}

Albert, L. (2005). Panorama de los plaguicidas en México, Proceedings of $7^{\circ}$ Congreso de Actualización en Toxicología Clínica, Tepic-Nayarit México, Septiembre del 2005.

Asociación de Agricultores del Río Sinaloa Poniente. (n.d.). La calabaza, Date of access 10/02/11, Available from:

<http:/ /www.aarsp.com/cms/index.php?option=com_content\&task=view\&id=24 \&Itemid $=85>$

CESAVEG-SAGARPA. (2005). Ficha técnica de Artogeia rapae L., Date of access 2/02/11, Available from:

<http://www.cesaveg.org.mx/html/fichastecnicas/fichatecnicaartogeiarapae.pdf>

CESAVEG-SAGARPA. (2005). Ficha técnica de Copitarsia incommoda Walker. Date of access 2/02/11, Available from:

<http://www.cesaveg.org.mx/html/fichastecnicas/fichatecnicacopitarsiaincomm oda.pdf>

CESAVEG-SAGARPA. (2005). Ficha técnica de Frankliniella occidentalis (Pergande), Date of access 2/02/11, Available from: 
<http://www.cesaveg.org.mx/html/fichastecnicas/fichatecnicaFrankliniellaoccid entalis.pdf $>$

CESAVEG-SAGARPA. (2005). Ficha técnica de Murgantia histrionica Hahn, Date of access 2/02/11, Available from:

<http://www.cesaveg.org.mx/html/fichastecnicas/fichatecnicamurgantiahistrion ica.pdf>

CESAVEG-SAGARPA. (2005). Ficha técnica de Plutella xylostella (Linnaeus) (Curtis), Date of access 2/02/11, Available from:

<http:/ / www.cesaveg.org.mx/html/fichastecnicas/fichatecnicaplutellaxylostella.pdf>

CESAVEG-SAGARPA (2005). Ficha técnica de Spodoptera exigua Hübner, Date of access 2/02/11, Available from:

<http://www.cesaveg.org.mx/html/fichastecnicas/fichatecnicaspodopteraexigua. pdf>

CESAVEG-SAGARPA. (2005). Ficha técnica de Trichoplusia ni Hubner, Date of access 2/02/11, Available from:

<http://www.cesaveg.org.mx/html/fichastecnicas/fichatecnicatrichoplusiani.pdf

CESAVEP. (2009). Manejo del Barrenador del Tallo (Trichobaris championi) y enfermedades de raíz en Tomate Verde, Date of access 18/02/11, Available from:

<http://www.cesaveg.org.mx/html/fichastecnicas/fichatecnicatrichobarischampioni>

Cortinas, C., (2000). Proyecto para Habilitar a México a formular el Plan Nacional de Implementación (PNI) para dar cumplimiento al Convenio de Estocolmo. Cortinas, Retrieved from

$<$ http://siscop.ine.gob.mx/descargas/diagnos/diag_comunicacion_participacion_ social.pdf>

Delgadillo, S., Kú, R., \& Vela, L. (2006). Modelación matemática del control de plagas en un cultivo de brócoli. Epígrafe Revista del Departamento de Matemáticas y Física de la Universidad Autónoma de Aguascaliente. UAA, Aguascalientes, México. Date of access 28/01/11, Available from:

< http://www.cns.gatech.edu/ luzvela/epigrafe/segnum/plagas.pdf>

FAO, PNUMA, OCDE \& OMS. (2000). Colección FAO: Eliminación de Plaguicidas, Estudio de referencia sobre el problema relacionado con las existencias de plaguicidas caducados, FAO, Retrieved from < www.fao.org/DOCREP/005/X8639S/x8639s02.htm>

FAOSTAT. (n.d.). Production and Crops, Date of access 25/02/11, Available from: $<$ http://faostat.fao.org/ default.aspx>

Fundación Produce Chihuahua. (n.d.). Cultivo tradicional de Cebolla, Date of access 21/02/11, Available from:

http:/ / sites.securemgr.com/folder11830/index.cfm?id31742=761\&fuseaction=bro wse\&pageid $=62>$

Fundación Produce Sinaloa. (2010). Viable el cultivo de brócoli en Sinaloa, trae consigo favorables expectativas, Date of access 18/02/11, Available from:

<http://www.fps.org.mx/divulgacion/index.php?option=com_content\&view=art icle\&id=646:viable-el-cultivo-de-brocoli-en-sinaloa-trae-consigo-favorablesexpectativas\&catid $=37$ : sinaloa-produce $\&$ Itemid $=373>$

INIFAP. (n.d.). Guía para la asistencia Técnica Agrícola de Nayarit Jitomate, Date of access 20/02/11, Available from:

<http:/ / www.cesix.inifap.gob.mx/guias/JITOMATE.pdf>

INIFAP-CEZAC. (2003). Potencial productivo de especies agrícolas en el estado de Zacatecas, INIFAP, Zacatecas, México.

INIFAP Chihuahua. (n.d.). La cebolla. Date of access 23/02/11, Available from: 
<http:// sites.securemgr.com/folder11341/index.cfm...>

INIFAP Chihuahua. (n.d). Paquetes Tecnológicos: Chile Jalapeño, Date of access 19/02/11, Available from: <http:// sites.securemgr.com/folder11341/index.cfm?...>

INIFAP-CIRNE Campo Experimental Sur de Tamaulipa. (2004). Paquetes Tecnológicos de Producción Agrícola Ciclo Otoño-Invierno 2004-2005, Date of access 18/02/11, Available from: < http://www.oeidrus-tamaulipas.gob.mx/paquetes_tec...>

INIFAP-CIRNO Campo Experimental Valle de Culiacán. (2003). Guía para la asistencia técnica agropecuaria para el área de influencia del Campo Experimental Valle de Culiacán (5 edition), INIFAP. Culiacán Sinaloa, México

INIFAP- SAGARPA- Gobierno del Estado de Sinaloa-Fundación Produce Sinaloa. (2010). Evaluación de híbridos de chile bell, Date of access 20/02/11, Available from: $<$ www.fps.org.mx>

INIFAP SLP. (n.d.). Tecnología de Producción para el Cultivo de Chile Serrano en la Huasteca de San Luis Potos (Tecnología No. 5), Date of access 22/02/11, Available from: <http://www.campopotosino.gob.mx/modulos/tecnologiasdesc.php?idt=61>

INIFAP SLP. (n.d.)Tecnología de Producción para el Cultivo de Jitomate en la Huasteca de San Luis Potosí (Tecnología No. 8.), Date of access 18/02/11, Available from: <http://www.campopotosino.gob.mx/modulos/tecnologiasdesc.php?idt=63>

Inter-Secretarial Commission for the control and use of pesticidas, Fertilizers and Toxyc Substances CICOPLAFEST. (1998). Catálogo oficial de plaguicidas. SEMARNAP, SECOFI, SAGAR y SSA, México D.F.

Instituto Nacional de Ecología, Secretaría de Medio Ambiente y Recursos Naturales. (n.d). Fichas técnicas de los Herbicidas incluidos en el catálogo CICOPLAFEST 2004, Date of access 4/03/11, Available from:

http://www2.ine.gob.mx/sistemas/plaguicidas/buscar/index.html>

Instituto Nacional de Ecología, Secretaría de Medio Ambiente y Recursos Naturales. (n.d.). Fichas técnicas de Plaguicidas por nombre común. Date of access 28/02/11, Available from: <<http://www.ine.gob.mx/dgicurg/plaguicidas >

Instituto Nacional de Ecología, Secretaría de Medio Ambiente y Recursos Naturales. México. (2005). Lista de Plaguicidas Prohibidos en México. Date of access 28/02/11, Available from: < http://www2.ine.gob.mx/sistemas/plaguicidas/lprohibi.html>

Instituto Nacional de Estadística, Geografía e Informática. (2007). Censo nacional agropecuario, INEGI, México.

Muñoz, C., \& Ávila, S. (2010). Los Efectos de un Impuesto ambiental a los plaguicidas. Instituto Nacional de Ecología, México, Date of access 23/02/11, Available from: <http://www2.ine.gob.mx/publicaciones/gacetas/460/plaguicidas.html>

Norzagaray, M., Campos, C., García, G., Llanes, O., Troyo, E., Muñoz S., \& Diéguez, P. (2010). Análisis de la producción agrícola extensiva en Sinaloa. Alternativas sostenibles para el uso sostenible del agua. $\mathrm{Ra}$ Ximhai, Universidad Autónoma Indígena de México. Vol. 6, No. 1, (enero-abril 2010), pp. 45-50.

PAN Internacional. (2009). Lista de plaguicidas altamente peligrosos (Lista de HHP de PAN), PAN, Retrieved from: < www.rap-al.org/articulos_files/ListaPAN_HHP.pdf >

Pérez, A., Segura, A., García R., Colinas, T., Pérez, M., Vázquez A., \& Navarro H. (2009). Residuos de plaguicidas organofosforados en cabezuela de brócoli (Brassica oleracea) determinados por cromatografía de gases. Revista internacional de contaminación ambiental, México. Vol. 25, No. 2, (Mayo 2009), pp. 103-110, ISSN 0188-4999.

SAGARPA. (2003). Plan Rector del Sistema Producto Chile Seco Jalisco. Diagnóstico Del Sistema Producto Chile. Date of access 21/02/11, Available from: 
<http://w4.siap.sagarpa.gob.mx/sispro/IndModelos/PRector/14_JAL/AG_Chile .pdf $>$

SAGARPA. (2005). Plan Rector Del Sistema Producto Chile San Luis Potosí, Date of access 18/02/11, Available from:

<http://w4.siap.gob.mx/sispro/IndModelos/PRector/24_SLP/AG_Chile.pdf>

SAGARPA-Gobierno del estado de Sinaloa- Fundación Produce Sinaloa- Centro de Validación y Transferencia de Tecnología de Sinaloa CVTTS. (2010). Manejo integral del cultivo de chile, Date of access 19/02/11, Available from: <www.fps.org.mx>

SAGARPA-Gobierno del Estado de Sinaloa- Fundación Produce Sinaloa-Centro de Validación y Transferencia Tecnológica de Sinaloa CVTTS. (2010). Variedades de Brócoli con potencial productivo, SAGARPA, Sinaloa México.

SAGARPA - INIFAP Centro de Investigación Nacional del Pacífico Sur. (2004). Guía para producir calabacita con fertirrigación en la mixteca oaxaqueña (Folleto técnico número 8), SAGARPA, Oaxaca, México.

SAGAR-INIFAP-CIRCE Campo Experimental Zacatepec. (2000). Brócoli, un nuevo cultivo para el estado de Morelos (Desplegable informativa No. 13), INIFAP, Morelos, México.

SAGARPA-INIFAP-CIRNE Campo Experimental las Adjuntas, Tamaulipas. (n. d.). Cultivo de chile Serrano, Date of access 22/02/11, Available from: <http://www.oeidrustamaulipas.gob.mx/paquetes_tec/PAQ.TEC.\%20CHILE\%20SERRANO\%20O1.pdf>

SAGARPA-INIFAP-CIRNO Campo Experimental Todos Santos, Baja California Sur. (2001). Áreas potenciales y tecnología de producción de cultivos en el Valle de Santo Domingo, B.C.S (Publicación Técnica Núm. 1), INIFAP, ISSN-1405-597X, Baja California Sur, México.

SAGAR-INIFAP-Fundación Produce Morelos. (1997). Guía para cultivar jitomate de temporal en Morelos (Folleto para productores. No 25), SAGAR, Zacatepec, Morelos México.

SAGARPA- INIFAP- Fundación Produce Morelos. (2008). Blanca Morelos, variedad de cebolla para siembra temprana en el estado de Morelos (Desplegable para productor No. 11), SAGARPA, Morelos, México.

SAGARPA-INIFAP-JICA. (2001). Guía para cultivar Tomate de Cáscara en el Estado de Morelos (Folleto para productores No. 29). Date of access 13/02/11, Available from:

< http:// producirmejor.com/Libros/hortalizas/hortalizas12.pdf >

SAGARPA-INIFAP-JICA. (2001). Manual de plagas y enfermedades del jitomate, tomate de cáscara y cebolla en el estado de Morelos (Publicación Especial No. 28). Date of access 19/02/11, Available from: <http:// producirmejor.com/Libros/hortalizas/hortalizas15.pdf>

SAGARPA-INIFAP-JICA. (2001). Manual para producir semilla de cebolla en el estado de Morelos (Folleto para productores No. 30), Date of access 12/02/11, Available from:

< http:// producirmejor.com/Libros/hortalizas/hortalizas16.pdf>

SAGARPA-INIFAP-JICA. (2001). Variedades de cebolla para trasplante en fecha muy temprana (Desplegable Informativa No. 23), Date of access 5/02/11, Available from:

< http:// producirmejor.com/Libros/hortalizas/hortalizas27.pdf>

SAGARPA-Programa de Sanidad Vegetal. (2005). Ficha técnica de Trips de la cebolla (Thrips tabaci Lindeman), Date of access 17/02/11, Available from: <http://www.cesaveg.org.mx/html/fichastecnicas/fichatecnicathripstabaci.pdf.>

Valdez, B., García, E., Cobo, J., \& López G. (2000). Impacto de los plaguicidas en la salud de los habitantes del Valle de Mexicali, México. Revista de Ecología Latinoamericana Ambiental, Vol. 6, No. 3, (2000), pp. (15-21), ISSN 1012-2494.

Wood Alan. (n.d.). Compendium of Pesticide Common Names. Date of access 8/03/11, Available from: <http://www.alanwood.net/pesticides/class_pesticides.html> 


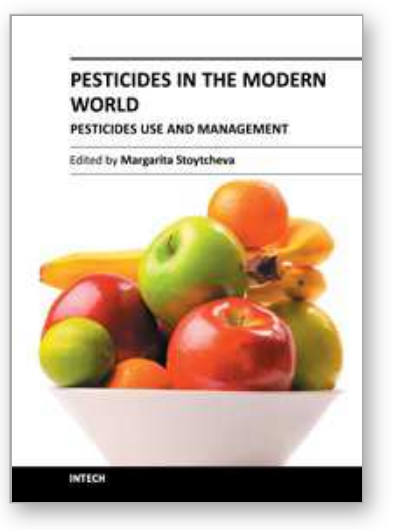

\author{
Pesticides in the Modern World - Pesticides Use and Management \\ Edited by Dr. Margarita Stoytcheva
}

ISBN 978-953-307-459-7

Hard cover, 520 pages

Publisher InTech

Published online 19, October, 2011

Published in print edition October, 2011

This book brings together issues on pesticides and biopesticides use with the related subjects of pesticides management and sustainable development. It contains 24 chapters organized in three sections. The first book section supplies an overview on the current use of pesticides, on the regulatory status, on the levels of contamination, on the pesticides management options, and on some techniques of pesticides application, reporting data collected from all over the world. Second section is devoted to the advances in the evolving field of biopesticides, providing actual information on the regulation of the plant protection products from natural origin in the European Union. It reports data associated with the application of neem pesticides, wood pyrolysis liquids and bacillus-based products. The third book section covers various aspects of pesticides management practices in concert with pesticides degradation and contaminated sites remediation technologies, supporting the environmental sustainability.

\title{
How to reference
}

In order to correctly reference this scholarly work, feel free to copy and paste the following:

Ma. A. Pérez-Olvera, H. Navarro-Garza and E. Miranda-Cruz (2011). Use of Pesticides for Vegetable Crops in Mexico, Pesticides in the Modern World - Pesticides Use and Management, Dr. Margarita Stoytcheva (Ed.), ISBN: 978-953-307-459-7, InTech, Available from: http://www.intechopen.com/books/pesticides-in-themodern-world-pesticides-use-and-management/use-of-pesticides-for-vegetable-crops-in-mexico

\section{INTECH}

open science | open minds

\author{
InTech Europe \\ University Campus STeP Ri \\ Slavka Krautzeka 83/A \\ 51000 Rijeka, Croatia \\ Phone: +385 (51) 770447 \\ Fax: +385 (51) 686166 \\ www.intechopen.com
}

\author{
InTech China \\ Unit 405, Office Block, Hotel Equatorial Shanghai \\ No.65, Yan An Road (West), Shanghai, 200040, China \\ 中国上海市延安西路65号上海国际贵都大饭店办公楼 405 单元 \\ Phone: +86-21-62489820 \\ Fax: $+86-21-62489821$
}


(C) 2011 The Author(s). Licensee IntechOpen. This is an open access article distributed under the terms of the Creative Commons Attribution 3.0 License, which permits unrestricted use, distribution, and reproduction in any medium, provided the original work is properly cited. 